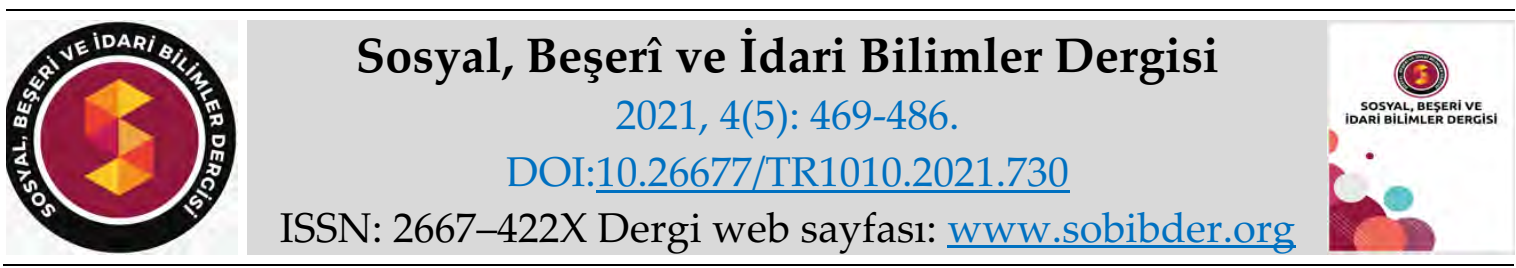

KAVRAMSAL MAKALE

\title{
Sualtı Turizmi ve Türkiye'de Sualtı Dalış Noktaları Hakkında Görgül Bir Araştırma (Ayvalık Örneği)
}

Dr. Öğr. Üyesi Yakup DİNÇ, Balıkesir Üniversitesi, Ayvalık Meslek Yüksekokulu, Balıkesir, eposta: yakdin@yahoo.com

ORCID: https://orcid.org/0000-0002-6533-3987

\section{Öz}

Günümüzde hizmetler sektörü dünyanın üç önemli sektöründen biri haline gelmiştir. Hizmetler sektörü içerisinde yer alan turizm, bugün özellikle gelişmekte olan ekonomiler için hem istihdam hem de döviz girdisi açısından tercih edilmektedir. Türkiye'nin tam anlamıyla 1980'li yıllardan itibaren keşfettiği ve önemli kazanımlar elde ettiği turizm bugün stratejik bir sektör haline dönüşmüştür. Türkiye; 2000'li yıllarda kitle turizminde sıkışmanın neticesi ile farklı ürün gruplarını öne çıkararak, turistik ürün çeşitlendirme stratejisini uygulamaya başlamıştır. Bu ürün gruplarından birisi de sualtı arkeolojisi ve sualtı dalış turizmidir. Üç yanı denizlerle çevrili olan Türkiye, Antik Çağ'dan bu yana deniz ticaret yollarının üzerinde yer almaktadır. Anadolu'nun coğrafi konumu ve sahip olduğu boğazlar Akdeniz'deki ticaret gemilerini Anadolu kıyılarında yer alan limanlara çekmiştir. Tarih boyunca Anadolu'yu çevreleyen denizlerde seyreden gemilerin bir kısmı, yol gösterici cihazlarının bulunmaması, sis, bilinmeyen kayalıklar ya da ani gelişen fırtınalar nedeniyle kıyılarımıza yakın batmıştır. Bugün; Türkiye kıyılarında hala keşfedilmeyi bekleyen birçok batık, gemi, uçak vb. kalıntılar vardır. Bu batıklar günümüzde ülkemizi sualtı dalış turizmi açısından oldukça cazip hale getirmektedir. $\mathrm{Bu}$ veriler ışı̆̆ında; Türkiye'de sualtı sporlarıyla ilgilenenler için dünyada eşine az rastlanan dalış bölgeleri bulunmaktadır. Ayrıca, bu spor dalı artık turistlerin de önemli bir aktivite alanı olmaya başlamıştır. Bu çalışmada; sualtı turizmi kavramsal boyutta incelenmiş ve dünyada önemli dalış noktaları hakkında bilgiler verilmiştir. Ayrıca; Türkiye'nin önemli dalış noktaları ve deniz faunası-florası kavramsal boyutta incelenmiştir. Çalışmanın son bölümünde; ülkemizin önemli bir turizm ve dalış destinasyonu olan Ayvalık Bölgesi'ndeki sualtı dalışıyla ilgili sorun ve çözüm önerilerinde bulunulmuştur.

Anahtar Kelimeler: Kelimeler; Sualtı Turizmi, Türkiye, Ekonomik Boyut, Ayvalık Makale Gönderme Tarihi: 25.02.2021

Makale Kabul Tarihi: 03.05.2021

\section{Önerilen Atıf:}

Dinç, Y. (2021). Sualtı Turizmi ve Türkiye'de Sualtı Dalış Noktaları Hakkında Görgül Bir Araştırma (Ayvalık Örneği), Sosyal, Beşeri ve İdari Bilimler Dergisi, 4(5): 469-486.

(C) 2021 Sosyal, Beşerî ve İdari Bilimler Dergisi. 


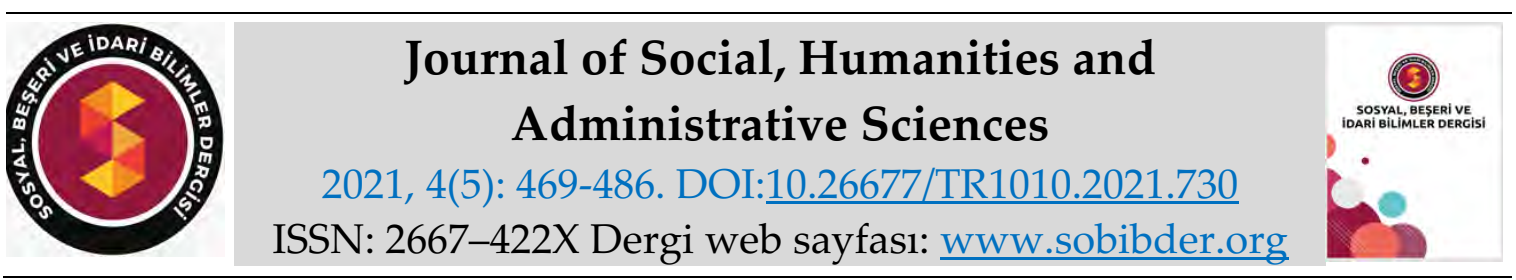

CONCEPTUAL PAPER

\title{
Underwater Tourism and An Empirical Study on Underwater Diving Locations in Turkey (The Ayvalık Sample)
}

Assistant Prof. Dr. Yakup DİNÇ, Balıkesir University, Ayvalık Vocational School, Balıkesir, email: yakdin@yahoo.com

ORCID: https://orcid.org/0000-0002-6533-3987

\begin{abstract}
Today, the services sector has become one of the three important sectors of the world. Tourism, which is within the services sector, is now preferred both for employment and foreign exchange inflows, especially for emerging economies. Turkey fully discovered tourism in the 1980s and has achieved significant gains since then. Tourism today has become a strategic sector in the country. Having been squeezed within mass tourism, Turkey has emphasized different product groups since the 2000s and started to implement a tourist product diversification strategy. One of these product groups is underwater archeology and underwater diving tourism. Surrounded by seas on three sides, Turkey is located on the sea trade routes since ancient times. The geographical position of Anatolia and the straits it has have attracted the trade vessels in the Mediterranean to the ports on the Anatolian coast. Throughout history, some of the vessels that sailed in the seas surrounding Anatolia have sunk close to the shores, due to the absence of navigational devices, fogs, unknown rocks or suddenly rising storms. Today, there are remnants of many shipwrecks, submerged aircraft, etc. that are still waiting to be discovered off the coasts of Turkey. These wrecks make Turkey very attractive in terms of underwater diving tourism. In light of these data, some of the rarest diving sites are located in Turkey for those who are interested in underwater sports. In addition, this sport is now becoming an important area of activity for tourists as well. In this study, underwater tourism has been studied at a conceptual level and information has been given about important diving points in the world. Also, important diving points of Turkey and marine fauna-flora were examined at a conceptual level. In the last part of the study, problems and solutions regarding underwater diving in the Ayvalık Region, which is an important tourism and diving destination of Turkey, have been proposed.
\end{abstract}

Keywords: Underwater Tourism, Turkey, Economic Dimension, Ayvalık.

Received: 25.02.2021

Accepted: 03.05.2021

\section{Suggested Citation:}

Dinç, Y. (2021). Underwater Tourism and An Empirical Study on Underwater Diving Locations in Turkey (The Ayvalık Sample), Journal of Social, Humanities and Administrative Sciences, 4(5): 469-486.

(c) 2021 Sosyal, Beşerî ve İdari Bilimler Dergisi. 


\section{Gíriş}

Turizm sektörü, dünyanın en önemli ve gelir getirici sektörlerinden biri olması dolayısıyla, 20. yüzyılın ikinci yarısından itibaren ülke politikalarında önemli yer tutmaya başlamıştır. Turizmde marka olan ülkeler mevcut turizm gelirlerini arttırmak amacıyla son yıllarda farklı turistik ürün gruplarına yönelmişlerdir. Bu strateji ile ülkenin mevcut turizmi zaman açısından yılın on iki ayına, mekan açısından da tüm ülkeye yayılması planlanmaktadır. Bu ürün gruplarından birisi de sualtı dalış turizmidir. Sualtı sporlarının gelişmiş toplumlarda bireylerin uğraş alanı olarak ortaya çıkması dünyada M.Ö. 5000'li yıllara, donanımlı dalışın ise 16.-19. yüz yüzyıllara dayandığı bilinmektedir. Bu sporla bugün dünyada ortalama 25 milyon kişinin ilgilendiğini, 4 mevsim yapıldığını, çevreci ve korumacı bir anlayışla yönetildiğini söyleyebiliriz.

Alternatif turistik ürün gruplarının çeşitlendirilmesinin bir sonucu olarak sualtı sporları günümüzde önemli olmaya başlamıştır. Özellikle Akdeniz'e kıyı olan ülkelerde yılın 12 ayında deniz suyu sıcaklığı bu sporu yapma imkanı sunmaktadır. Ülkemizde ise; sualtı florası ve faunası özellikleriyle Ege, Akdeniz ve Saros Körfezi önemli dalış noktalarıdır. Doğu Akdeniz Bölgesinde Türkiye deniz kıyılarının özellikle bazı kesimleri iyi korunmuş durumdadır. Deniz flora ve faunası bakımından da oldukça zengin bir bölgedir. Dalış turizmi henüz hak ettiği popülerliği kazanmasa da sualtı arkeolojik değerleri bakımından Türkiye, dünyanın en önemli ülkeleri arasında bulunmaktadır. Sualtı batık zenginliği açısından oldukça büyük bir potansiyele sahip olan ülkemiz, dünyanın ilk bilimsel sualtı kazısının da ev sahipliğini yapmaktadır. Bu nedenle Bodrum Sualtı Arkeoloji Müzesi'nin dünyanın en önemli sualtı müzesi özelliği taşıması hiç de şaşırtıcı değildir. Dünyadaki su altı turizminden en fazla payı flora ve fauna zenginliği dolayısıyla Kızıldeniz ve Maldiv Adaları, elde etmektedir

Dalış turizmi deneyimi yaşamak isteyen tüketiciler birçok motivasyonlara sahiptir. Bu motivasyonların kuşkusuz en önemlileri dalış yapanların ihtiyaçları ve farklı sualtı fauna ve flora görme ihtiyaçlarıdır. Bu nedenle her yıl farklı ve ilginç batıklara dalma ihtiyacı duyarlar. Ülke ve dalış noktaları ile ilgili tercihlerini buna göre yaparlar. Ülkemiz bu noktada bu ihtiyaçlara cevap verebilecek farklı batık noktalarına ve zengin sualtı fauna ve florasına sahiptir. Dolayısıyla bu gruplara yönelik farklı pazarlama çalışmalarına ve stratejilere ihtiyaç vardır.

\section{SUALTI TURIZMİ, KAVRAMSAL ÇERÇEVE ve SORUNLAR}

Günümüzde turistlerin beklentilerinde meydana gelen talep değişiklikleri, içgüdüsü ve bilinmeyeni keşfetme arzusu turizm sektöründe yeni eğilimleri beraberinde getirmiştir. Zamanla su sporlarına; merak ve ilginin artma talebine bağlı olarak bu özel alana yatırımlardaki artış "sualtı dalış turizmi" adı verilen yeni turizm türünü ortaya çıkarmıştır. Sualtı dalış turizmi; sualtı dünyasının fauna, flora ve arkeolojik kültür varlıklarını görmek, fotoğraflamak, filme almak ve sportif balık avlama amaçlı olarak gerçekleştirilen tanıtım, sportif ve eğitim amaçlı dalışlar ile kıyıda verilen konaklama ve ağırlama hizmetleri içine alan bir turizm çeşitidir. (Yaşar, 2011: 36). Fakat dalış turizmini etkileyen birçok parametrenin varlı̆̆ı, kavramı tanımlamayı daha zor hale getirmektedir (Gorrad ve Gössling, 2008:4). Dünya Turizm Örgütü (WTO); dalış (scuba) turizmini, dalış aktivitelerine katılmak için kişilerin amaçlı olarak başka destinasyonlara seyahat etmesi olarak tanımlamaktadır. Destinasyonun çekiciliğine etki eden faktörlerin başında sadece dalış kalitesi gelmekte ise de konaklama ve ulaşım kolaylığ diğer belirleyici etkenlerdir (Bideci, 2014:47). Bu aktiviteye katılanlar kendi bulundukları yerler ile sınırlı kalmamışlar, yılın 12 ayında dalış sporu için farklı dalış bölgelerine giderek bu 
sporunun tanınmasında tercih edilmesinde olmasında etkin rol oynamışlardır. Nitekim dalış yapanların birçoğu aktiviteyi gerçekleştirmek amacıyla kuzey yarım kürenin gelişmiş ülkelerini tercih etmektedirler ki bu durum Avrupa'nın üçte birinden fazla bir alanı kapsamaktadır (Bideci, 2014:47).

Alternatif Özel ilgi turizminin en önemlilerinden biri olan dalış turizmi pahalı bir boş zaman değerlendirme faaliyetidir. Dalış Alanlarının kendine has özelliği ve çeşitliliğinin yanında dalma faaliyeti için kullanılan ekipmanlar bu pahalılı̆̆a neden olan faktörlerin başında gelmektedir. Sualtı sporları, özellikle dalış sporu, maliyetli olduğu kadar örgütlü yapılması gereken bir spor dalıdır. Bu sporun uygulayıcıları; donanım, coğrafi çekicilik, mali imkanlar, üst düzey teknik bilgi ve yardımlaşma esasları gibi bilgilere sahip olmak zorundadır. Yılda 10 milyon Avrupa'dan dalış sporu meraklılarının bu dalış sporu nedeniyle her yıl Mısır'a gittiği göz önüne alınırsa, bu turizm çeşidinin destinasyon ülkeleri için son derece önemli bir potansiyel olduğu görülecektir (Erkut ve Paker, 2014: 134). Dalış turizminin önemi ile ilgili bir başka veri ise şudur; Avrupa Birliği ülkelerinde 4 milyona yakın sertifikalı dalgıç bulunmaktadır. Bunların dörtte biri, hem farklı yerlerde dalış yapmanın zevkini yaşamak hem de yeni dalış deneyleri kazanmak için her yıl farklı bölgeleri ziyaret etmektedirler (Top, Yolak ve Thomas, 2003: 8).

Türkiye'nin sahip olduğu sekiz bin beş yüz km'lik kıyı şeridi boyunca yaklaşık olarak 3000 bitki ve hayvan türü bulunmaktadır (Top vd., 2013: 5). Bu sahip olduğumuz değerlerin korunması ancak bireylerin ve toplumun çevre hakkında bilinçlenmesiyle mümkün olacaktır. $\mathrm{Bu}$ bölgelerin geliştirilmesi, korunması ve sürdürülebilirliğinin sağlanması su altı turizmi için temel zorunluluktur. Dolayısıyla sürdürülebilir turizm projelerine daha fazla önem verilmeli ve yerel halkın da planlama aşamasından başlayarak bu sürece dahil edilmelidir. (Polonsky ve Rosenberger, 2001:24). Yerel ölçekte bu güven ve işbirliğinin oluşturulması zaman ve sabır gerektirmektedir. Sürdürülebilir turizm projelerinin başarısında her zaman yöre halkının memnuniyeti önemlidir (Akşit, 2007: 455). Bu nedenle, turistik ürün grupları arasında yer alan su altı turizminin geliştirilmesi için hem çevrenin hem de su altının korunması büyük önem taşımaktadır. Dolayısıyla bu turistik ürün hakkında yerel halkı bilgilendirilmek, projelere katılımını sağlamak ve destek için eğitmek gerekmektedir. Turizmin sürdürülebilirliği açısından sualtı dalış faaliyetleri ve eko-sistemin korunması konusunda yerel halkın ve turistlerin bilinçlendirilmesi, kuralların ve yasaların sıkı bir şekilde uygulanması turistik ürünün başarısı için önemlidir (Yarmacı vd., 2017:70). Ayrıca şunu belirtmek gerekir sualtı turizminin bölgeye ve sualtına verdiği zararlardan da bahsedilmelidir. Örneğin; Çevreyi ve deniz faunasını düşünmeden bilinçsizce gerçekleştirilen dalış aktiviteleri hem çevreye hem su altı değerlerine zarar vermektedir. Yine; dalış teknelerinin bekleme anında teknelerin hareket etmemesi için attığı çapalar, sürüklenme sırasında zeminde oluşan bitkilere zarar vermektedir. Su altında bulunan endemik balık türlerinin sportif balıkçılık adı altında avlanması, sualtı ekosistemine verilen başka bir zarar çeşididir. Sualtı Araştırma Derneği (2009) tarafından BodrumKaş bölgesinde yapılan araştırmaya göre; bu bölgedeki sualtı eko-sistemi büyük bir tahribata uğramıştır. Sağlıklı bir eko-sistemde yaklaşık on iki ile yirmi metrelere kadar üzeri yosunlar (algler) ile kaplı olması gereken kayaların, adeta nükleer bir patlama olmuş gibi çıplak ve çorak durumda olması zararın boyutunu ortaya koymaktadır.

\section{DÜNYADA SUALTI TURIZMI ve EKONOMIKK BOYUTU}

Sualtı turizmi ve su altı sporlarına olan talep ve ilgi gün geçtikçe kişilerin gelir düzeylerinde ki olumlu gelişmelere paralel olarak artmaktadır. Avrupa' da yaklaşık 25 milyon kişi su sporlarına ilgi duymakta ve bu sporu ülkelerinin dışında farklı destinasyonlarda da yapmayı 
arzulamaktadırlar. Dünyada önemli dalış merkezleri arasında; Kızıldeniz, Karayipler, Florida, Maldiv Adaları, Endonezya, Filipinler, Tayland, Akdeniz de Malta gibi destinasyonlar vardır. Güney Avustralya Great Barrier Reef - SS Yongala Batığı, Bahama Adaları, Kanada-Baffin Adası, Papua New Guinea, Milne Bay, Mısır Kızıldeniz Aida II Batığı, Güney Afrika Ümit Burnu-Beyaz Köpek Balığı, Brezilya-Frenando de Noronha, Endonezya-Komodo, Maldiv Adaları, Kaliforniya-Channel Adaları dünyada bilinen en önemli dalış noktaları arasında yer almaktadır. Dünyanın önde gelen dalış alanlarının büyük bir çoğunluğu tropikal bölgelerdeki ve özellikle mercan resiflerinin bulunduğu bölgelerdir. Dalgıçların kendi rekreasyonel fırsatlarına ulaşma eğilimi göstermeleri dolayısı ile onlara ulaşmanın çok çeşitli yollarından birisi de uluslararası seyahatlerdir (Bideci, 2014:47). Dünya Turizm Örgütü'nün (WTO) verilerine göre; sualtı dalışı yapanların sadece 3'te 1'i düzenli olarak deniz aşırı dalış tatili seyahatleri yapmaktadır. Geri kalan dalgıçlar ya günlük tur bazında evlerine yakın ya da kendi ülke sınırları içinde bir günden fazla süren turlar şeklinde dalış aktivitelerini tercih etmektedirler (Gorrad ve Gössling, 2008:5-6).

Dünyada farklı ancak önemli bir turistik ürün grubu olan sualtı turizmini ekonomik açıdan da irdelemekte fayda vardır. Son bilimsel çalışmalar çerçevesinde; sualtı sporunun dünyadaki ekonomik hacmi şöyledir, Batı Akdeniz Kalkınma Ajansı'nın (BAKA) 2012 yılında yayınladığı Ekoturizm Sektör Raporu'na göre; Florida Keys Bölgesi'nde yapılan dalışlar, yıllık 75 milyon ABD doları gelir sağlamaktadır. Karayip Adaları'nda büyük ölçüde eko-turizmden oluşan turizm endüstrisi 2018 yılında 32 milyar ABD Doları hacme ulaşmıştır (https://www.statista.com). Karayip Adaları'nda sadece resif ziyaretlerinden $\mathrm{km} 2$ başına tahmini olarak 100.000-600.000 ABD Doları gelir sağlanmaktadır. Kosta Rika'yı ziyaret eden eko-turistlerin \%46'sı Amerika ve Kanada, \%16'sı AB ülkelerinden olup, ortalama bir turist en az 1.000 ABD Doları harcamaktadır. Ekvator'daki Galapagos Adaları'na ziyaret, 80'li yıllardan itibaren hızla artmış ve 2017 yılında 241.800 ziyaretçi sayısına ulaşılmıştır (https://www.nytimes.com). Bu gezilerin Ekvator ekonomisine katkısı yıllık 100 milyon ABD Doları aşmış durumdadır. Hollanda Antilleri'nde aletli dalış (scuba diving) yapan turistlerden 95 ABD Doları ücret alınmaktadır (https://www.divescover.com). Bu ada; sadece aletli dalışdan yıllık 30 milyon ABD Doları gelir sağlamaktadır. Avustralya'da bulunan, $345.950 \mathrm{~km} 2$ alanı kaplayan Dünya Mirasları Listesi'ndeki 'Great Barrier Reef Marine Parkını' 2020 yılında 1,79 milyon turist ziyaret etmiştir ve sadece bu turistlerden 1 Milyar Avustralya Doları (988 Milyon ABD Doları) gelir elde edilmektedir (https://www.gbrmpa.gov.au). Söz konusu gelirler doğrudan sualtı dalış turizminden elde edilmese de sualtı dalış aktivitelerinin bu gelirde büyük bir rolü olduğu bilinmektedir (Yarmacı vd., 2017:70).

Bir Akdeniz ülkesi olan Mısır, doğu ile batının birleşim noktasında bulunması, kültürel ve arkeolojik değerleri ile yüzyıllar boyunca ilgi çekmiştir. Mısır aynı zamanda medeniyetlerin gelişmesine de beşiklik etmiştir. Bu belirttiğimiz faktörler, Mısır'ın tarihi mirasına çok büyük katkılarda sağlamıştır. Tarihi mirası sayesinde uluslararası kitlesel turist akınının önemli bir kısmı bu destinasyon ülkesine yönelmektedir. Tarihi yerler, kültür, güneş, kum ve deniz turizmiyle çok erken adını duyuran Mısır özellikle son 20 yılda sualtı zenginlikleriyle ünlü Kızıldeniz bölgesinde dalış turizmi önemli bir turistik ürün grubu olmuştur. Bu bölge; uygun konaklama seçenekleri, diş ve iç ulaşım sorununun geçmiş yıllara oranla artan bir hızla çözülmesi ve iyileştirilmesi sayesinde dünyanın en iyi sualtı dalış merkezlerinden birisi olmuştur. Örneğin; 2019 verilerine göre: turizm, 14,5 milyar dolar gelir getiren, nüfusun \%9.7'sine iş sağlayan, GSMH'nin \%9.7'sini yani 29,5 milyar dolar getirisi olan bir sektördür (www.wttc.org). Mısır'da turizm gelirinin önemli bir bölümü Kızıldeniz bölgesinden ve sualtı turizminden sağlanmaktadır. Bu bölge mercanlar ve deniz altı yaşamı bakımından dünyanın en 
ünlü yerlerinden biri olarak tanınmaktadır. Mısır dünyanın en büyük dalış gemi filosuna (liveaboard) belirli sürelerle içinde dalgıçların yaşamasına da uygun olan dalgıç gemisi) sahiptir. Yıllık olarak dünyanın her yerinden 540 bin kişi Mısır Kızıldeniz bölgesine sadece dalış yapmak için gelmektedir. Bu dalış turist grubu diğer turistlere göre ülkede daha fazla harcama yapmaktadır. Mısır'daki turizm aktivitelerinin \%75'i aletli (scuba) dalışı içeren eğlence odaklıdır ve Kızıldeniz'de yoğunlaşmıştır. Kızıldeniz dünyadaki en iyi dalış yerlerinden birisi olarak kabul edilmektedir. Yılın büyük bir bölümünde dalış yapılabilen Kızıldeniz, 1000'den fazla omurgasız türü, 200'den fazla yumuşak ve sert mercan türünü yoğun olarak barındıran, sualtı dünyasının 7 harikasından biri (Mısır Riviera'sı olarak da anılır) olarak kabul edilir. Ülkeye ait bu veriler 1100 balık türünü içeren bir deniz eko-sisteminin temelini oluşturur. Yüksek düzeydeki endemiklik oranı Mısır'da aletli (scuba) dalışı çok özendiren önemli faktörlerden birisidir. Deniz suyu sıcaklığının yılın büyük bir bölümünde dalış için uygun olması ve en sıcak denizlerden biri olarak kabul edilmesi bölgeye olan talebin önemli nedenleridir.

Eşsiz bir görünüm, berrak sular ve tropikal bir deniz yaşamı olan Kızıldeniz, köpekbalıklarından yunuslara, çok ilginç batıklar koleksiyonundan sı̆̆ resiflere, mercan kayalıklarından denizyıldızlarına kadar çok görkemli bir sualtı zenginliği sunar. Başka yerlerde çok canlı (parlak ve göz alıcı) resifler okyanusa kadar uzanarak karmaşık labirent yaylaları, atöller (lagunler), mağara ve bahçeler oluşturur. Bir yanda mercandan bahçeler varken aniden bu manzara bir duvarın, yüzlerce metre derine inerek karanlık okyanus diplerinde kaybolduğu hale dönüşebilir. Mısır Kızıldeniz'i, Avrupalı dalgıçlar arasındaki yüksek popülerliği ve liveaboard türü teknelerde dalış yapabilme seçenekleri nedeniyle dalgıçlar tarafından tercih edilmektedir.

\section{TÜRKIYYE'DE SUALTI DALIŞ NOKTALARI HAKKINDA GÖRGÜL BİR ARAŞTIRMA}

Çağımızda hizmetler sektörü dünyanın üç önemli sektöründen bir haline gelmiştir. Hizmetler sektörü içerisinde yer alan turizm, bugün özellikle gelişmekte olan ekonomiler için istihdam hem de döviz girdisi açısından tercih edilmektedir. Türkiye'nin tam anlamıla 1980'li yıllardan itibaren keşfettiği ve önemli kazanımlar elde ettiği turizm bugün stratejik bir sektör haline dönüşmüştür. Türkiye; 2000'li yıllarda kitle turizminde sıkışmanın neticesi ile farklı ürün gruplarını öne çıkararak, turistik ürün çeşitlendirme stratejisini uygulamaya başlamıştır. Bu ürün gruplarından birisi de sualtı arkeolojisi ve sualtı dalış turizmidir. Türkiye doğal ve kültürel kaynaklar bakımından oldukça zengindir. Türkiye'nin coğrafi konumu ve sahip olduğu boğazlar Akdeniz'deki ticari yük gemilerini Anadolu kıyılarında bulunan ticari limanlara çekmiştir. Bu limanlar; her zaman ticari gemilere ikmal sağlama mekanları olmuşlardır. Tarih boyunca Anadolu'yu çevreleyen denizlerde ulaşım sağlayan gemilerin bir kısmı, yol gösterici cihazlarının bulunmaması, sis, bilinmeyen kayalıklar, hava şartlarından kaynaklanan fırtınalar sebebiyle kıyılarımıza yakın bölgelerde batmıştır. Günümüzde; Türkiye kıyılarında hala keşfedilmeyi bekleyen birçok batık, gemi, uçak vb. kalıntılar mevcuttur. Bu batıklar günümüzde ülkemizi sualtı dalış turizmi açısından oldukça cazip hale getirmektedir. Bu veriler ışığında; ülkemizde sualtı rekreasyonel faaliyetlere ilgi duyanlar için dünyada eşine ender rastlanan dalış noktaları ve bölgeleri bulunmaktadır. $\mathrm{Bu}$ dalış bölgeleri, sualtı zenginliklerinin yanı sıra, gizliliğini ve çekiciliğini hâlen sürdürmekte ve keşfedilmeyi beklemektedir (Yaşar, 2011:34). Ayrıca, bu spor dalı artık turistlerin de önemli bir aktivite alanı olmaya başlamıştır. 
Türkiye'nin mevsimsellik özelliği ılıman iklim olması nedeniyle dalış bölgeleri dört mevsim 12 ay dalış yapma imkânına sahiptir. Günümüzde, farklı sualtı coğrafyası ve batıklar dalış sporuyla ilgilenen yerli ve yabancı turistlerin tercih ettiği bir yer olarak karşımıza çıkmaktadır. $\mathrm{Bu}$ anlamda; dünyada en önemli elli dalış merkezinden birisi Antalya- Kaş ilçesidir. Sualtı dünyası açısından oldukça zengin olan bu bölgede; batıklar, mağaralar, kanyonlar, resifler, tüneller, uçaklar ve zengin sualtı faunasını görmeniz mümkündür (Erkurt ve Paker, 2014: 51). Türkiye'de bulunan önemli su altı dalış bölgeleri hakkında yaptığımız araştırmaya göre; Karadeniz kıyıları dalış sporları için çok uygun değilken, Marmara, Ege ve Akdeniz kıyılarında dalış sporları için oldukça önemli dalış noktaları vardır (www.ktb.gov.tr). Bu dalış noktaları ile ilgili yaptı̆̆ımız görgül araştırmada öne çıkan bölge ve batıklar şöyledir;

İstanbul ve Marmara Denizi: İstanbul, Marmara Denizi Dalış Noktaları

Antalya Bölgesi: Antalya- Kemer Bölgesi, Antalya- Tekirova Bölgesi, Antalya- Kaş Uçak Batı̆̆ı, Antalya- Kalkan Bölgesi, Antalya- Gök Mağarası, Antalya- Uluburun Antik Batığı, AntalyaSuluin Mağarası, Antalya- (Gelidonya) Antik Batığı, Antalya- Fransız (Sosyete) Batı̆̆ı, AntalyaFalezler, Antalya- Sıçan Adası, Antalya- B-24 Savaş Uçağı Batığı, Antalya- Alanya Bölgesi

Mersin Bölgesi: Mersin Bölgesi

Muğla Bölgesi: Muğla- Bodrum Bölgesi, Muğla- Datça Bölgesi, Muğla- Marmaris Bölgesi

Çanakkale Bölgesi: Çanakkale- Saros Bölgesi, Çanakkale- Bebek ve Minnoş Kayalıkları, Çanakkale- Gökçeada ve Bozcaada

İzmir Bölgesi: İzmir- Çeşme Bölgesi

Aydın Bölgesi: Aydın- Kuşadası Bölgesi

Balıkesir Bölgesi: Balıkesir- Ayvalık

Ülkemiz sınırları içerisinde kalan ve önemli dalış noktaları olarak ifade edebileceğimiz bu dalış bölgeleri sualtı fauna ve florası ile de oldukça zengindir. Bu bölgeler aşağıda ayrıntılı bir şekilde analiz edilmiştir;

\section{İstanbul ve Marmara Denizi Dalış Bölgesi}

İstanbul-Marmara Denizi Dalış Alanları: Prens Adaları olarak adlandırılan adalar bölgesi İstanbul sınırları içerisinde bulunmaktadır. Adalar bölgesinde birbirinden farklı dalış noktaları bulunan yedi farklı ada mevcuttur. 


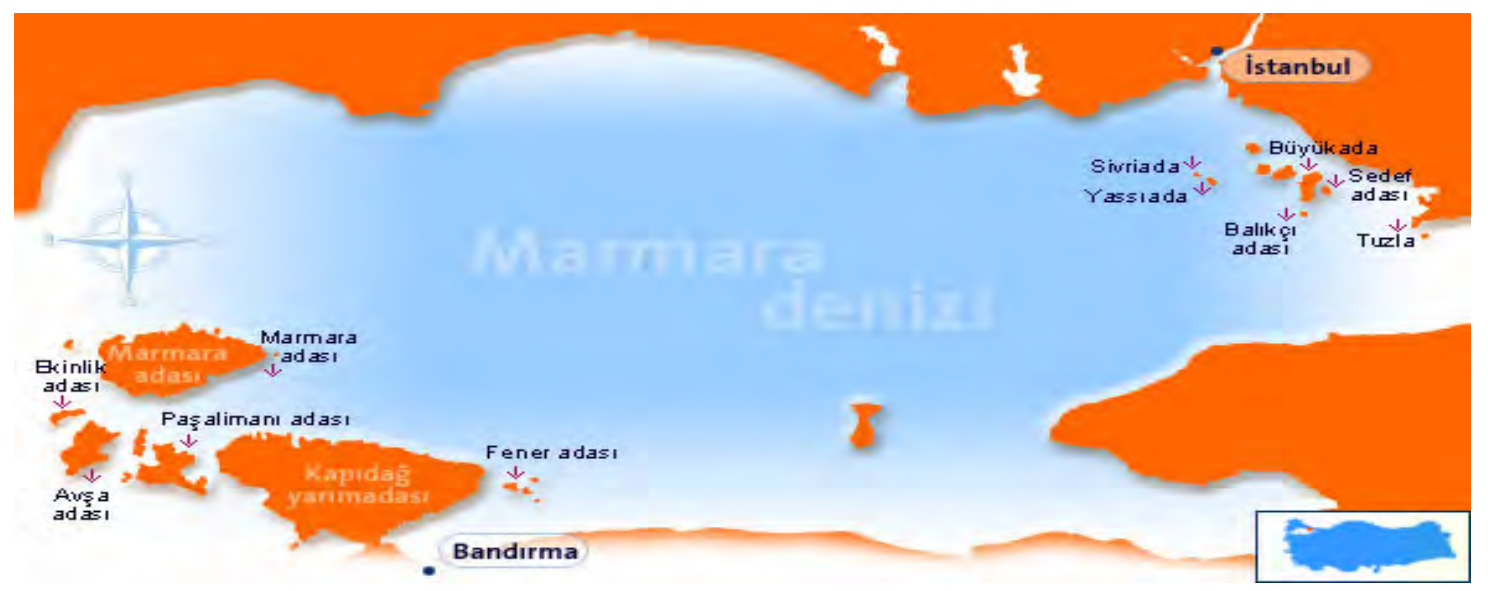

Yassıada Dalış Alanı: Kadıköy'e yaklaşık 6 mil uzaklıkta olan adada yerleşim alanı bulunmamaktadır. Demokrasi adası diye de bilinir.

Sivriada Dalış Alanı: Ada Yassıada'ya 1,7 km, Kadiköy sahiline ise 11 km uzaklıktadır.

Sedef Adası Dalış Alanı: Ada bölgesinde Bizans Batığı'nın bulunması nedeniyle dalış yapılması yasak bölgeler arasında yer almaktadır. Çeşitli mercan oluşumları, beyaz renkli yumuşak mercanlar fotoğrafçılara güzel manzaralar sunmaktadır.

Büyükada Dalış Alanı: Büyükada adalar bölgesinin en büyük adasıdır. Kumluk alanlarda yer alan kabuklu deniz canlıları fotoğrafçılara güzel manzaralar sunmaktadır.

Nehandros Dalış Alanı: Bu adanın çevresinde birçok dalış noktası vardır. Bu alan Balıkçı veya Eşek Adası olarak bilinmektedir.

\section{Antalya Bölgesi}

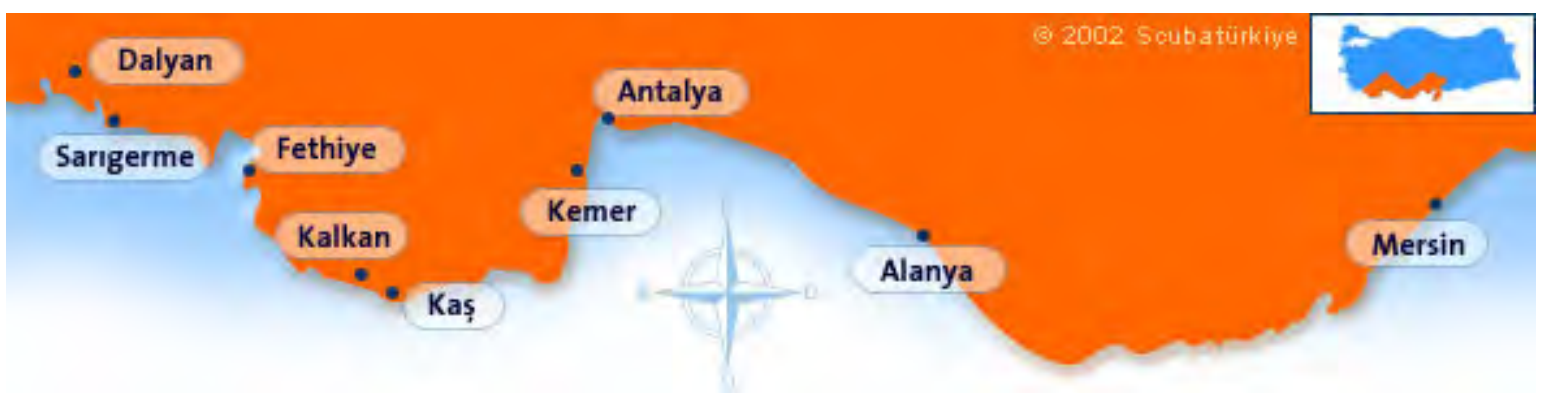

Antalya-Kemer Bölgesi Alanı: Kemer Limanına 1,5 km kadar mesafede 25 metre derinlikte kum üzerinde duran Paris Batığı II Dünya savaşında batan Fransız yük gemisine aittir.

Antalya-Tekirova Bölgesi Alanı: Tekirova açıklarında bulunan küçük adalardan (üç adalar bölgesi) oluşan bir dalış bölgesidir. Dip yapısı zengindir olması ve denizin dibinin görüş netliği nedeniyle tercih edilen dalış bölgelerinden birisidir. Kemer yat limanına 45 dakika mesafededir.

Antalya Kaş Uçak Batığı Alanı: Yunan Meis Adası ile Kaş destinasyonu arasındaki son dalış noktasıdır. Bu dalış destinasyonunda resif 80 metreye kadar uzanmaktadır. 35 metreden sonra renklenen kayaların etrafında, kuma yatmış iri orfozlar ve akyalar görmek mümkün olmaktadır (Şenok, 2011:3). 


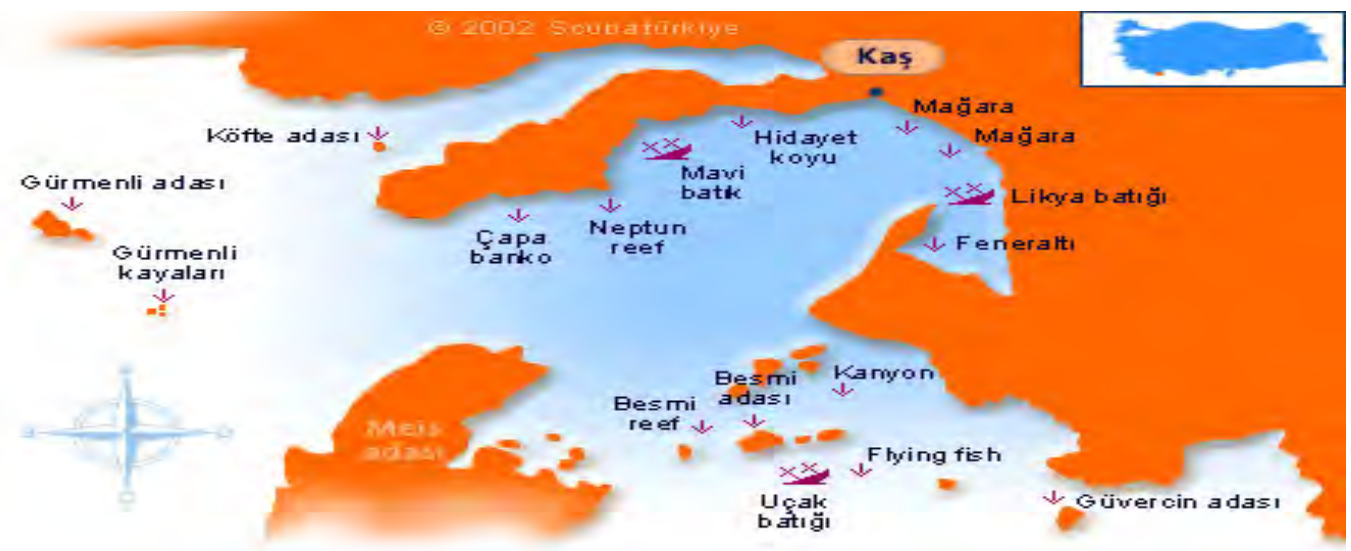

Antalya-Kalkan Bölgesi Alanı: Kalkan açıklarında uzun yıllar öncesinde batmış olan İngiliz kargo gemisi batığı, Sakarya batığı ile bölgenin en popüler dalış noktaları haline gelmiştir (Top vd., 2013: 9). Kalkan suları, ciddi dalışlar yapıp form tutmak isteyenler için çok uygundur.

Antalya-Gök Mağarası Alanı: Asya'nın dalışı yapılmış en derin mağaralarından biri olan Gök Mağarası, Finike destinasyonu dalış alanında bulunmaktadır.

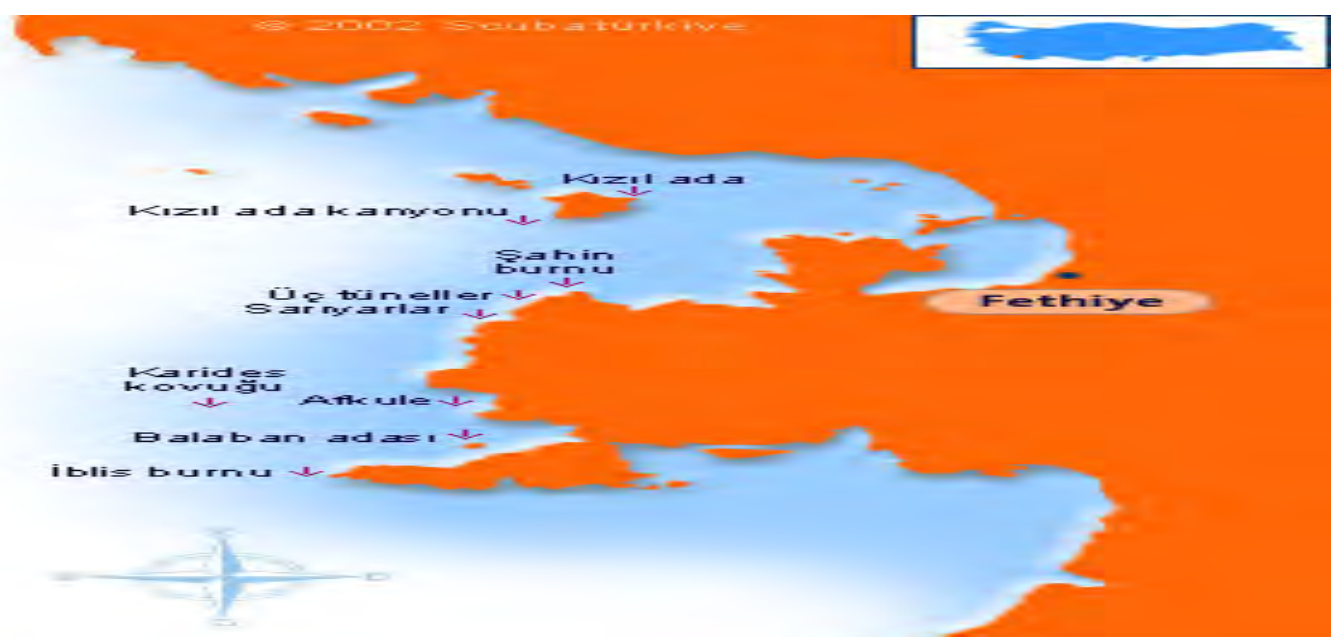

Antalya Uluburun Antik Batığ Alanı: Kaş'ın 8,5 km güney doğusunda Uluburun'un doğu ve 60 metre açığında bulunan batık M.Ö. 14. yy. yük gemisi kalıntısıdır.

Antalya Suluin Mağarası Alanı: Kırk göz çevresinde yer alan Suluin mağarası, içindeki dikit ve sarkıtlardan kuruluğu nedeniyle sualtı mağaralarındandır.

Antalya-Gelidonya Antik Batığı Alanı: Gelidonya batığı Antalya körfezinin batı ucunda yer almaktadır. Taşlık burnu çevresinde yol alırken kayalara vurarak batan yük gemisidir.

Antalya, Fransız (Sosyete) Batığı Alanı: Yat Limanının hemen açı̆̆ında, şamandıranın altında bulunmaktadır.2. Dünya savaşı sırasında batırılan "San Didier" adlı Fransız savaş gemisine ait olan bir batıktır.

Antalya Falezler Alanı: Falez konumları; 14 metre ile 25 metre derinlik arasındadır. Karadan ulaşılabilen bölge Lara ve Konya altı plajları arasında kalmaktadır. 
Antalya Sıçan Adası Alanı: Sahile yakın kısmında sı̆̆ bir derinliğe sahip olan Sıçan Adasının dip özelliği kum olmasıdır. Limana birkaç kilometre mesafede olan ada dalgıçların dikkatini çeken dalış yeridir.

B-24 Savaş Uçağı Batığı Alanı: Antalya'nın Manavgat ilçesi civarlarında, iki yüz metre açıkta yatan batık. Uçağa dalış özel izin gerektirmektedir (Demirtaş, 2012: 1083).

Antalya-Alanya Bölgesi: Bu bölgede önemli dalış noktaları şunlardır;

Akvaryum Alanı: Derinlik 4 ile $25 \mathrm{~m}$ arasında farklılık göstermektedir Alanya limanına en yakın olup yaklaşık $5 \mathrm{dk}$. uzaklıktadır.

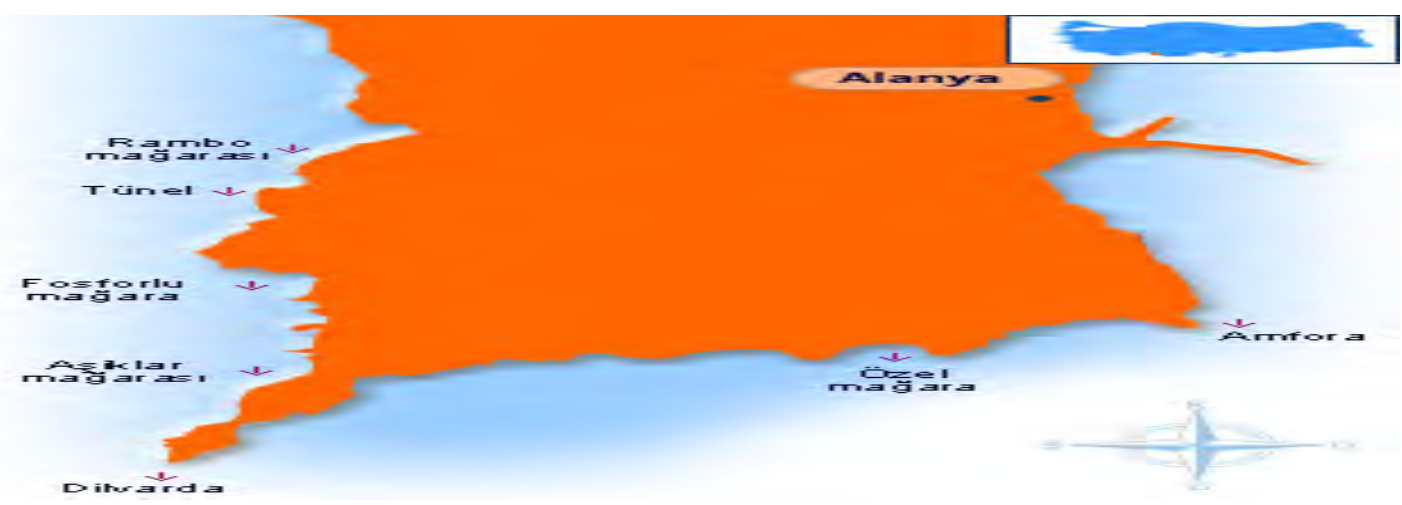

Anfora Alanı: Limana en yakın ikinci dalış bölgesi olup tekne ile yaklaşık 5 dakika uzaklıktadir.

Korsan Alanı: Alanya limanına 8 ila 10 dk. ulaşım mesafesindedir.

Teras Alanı: Alanya limanına normal tekne ile yaklaşık olarak $10 \mathrm{dk}$. mesafededir. Derinlik 7 ila $25 \mathrm{~m}$ arasında farklılık göstermektedir.

Orta Mağara Alanı: Alanya limanına mevkisine 12 dk. mesafededir. En az $15 \mathrm{~m}$ en çok $34 \mathrm{~m}$ derinliğe ulaşmaktadır.

Aşıklar Mağarası Alanı: Alanya limanına 15 dk. uzaklıktadır. Bölgenin derinliği $10 \mathrm{~m}$. ila $34 \mathrm{~m}$. arasında değişlik göstermektedir.

Dilvarda (doğu) Alanı: Limana uzaklığı 17 dk. mesafededir. Alanya kalesinin en uç noktası olan burunun doğu tarafında yer almaktadır.

Dilvarda (batı) Alanı: Alanya kalesinin en uzak uç noktası olan burunun batı tarafı olup, limana $20 \mathrm{dk}$. uzaklıkta bulunmaktadır.

Fosforlu Mağara Alanı: Bu bölgenin derinliği 8 ila $33 \mathrm{~m}$ arasındadır. Limana $20 \mathrm{dk}$. uzaklıktadır.

Kırıktaş Alanı: Normal tekne ile gidildiğinde Alanya limanına $20 \mathrm{dk}$. Mesafededir. Derinlik 5 ila $20 \mathrm{~m}$ Arasındadır.

Tünel Alanı: Limana 22 ila 25 dk. Mesafededir. Kalenin batı kısmında $13 \mathrm{~m}$ derinlikte giriş ve çıkışı imkanı olan bir tüneldir. 
Rambo Alanı: Tekne ile yolculuk yapıldığında limana $25 \mathrm{dk}$. uzaklıktadır. Derinliği 13 metredir. Ulaşım olarak limana en uzak noktadadır. Kleopatra plajına yakın, Alanya'nın en tercih edilen dalış alanlarından biri olduğu söylenebilir.

\section{Mersin Dalış Bölgesi}

Mersin Dalış Bölgesi: Temiz deniz suları ile destinasyon, dalgıçlara çok değişik imkanlar sunmaktadır. Dana adasının batı burnu kısmında ters dönmüş olarak yer alan yük gemisi dalgıçlar tarafından tercih edilen batıklar arasında bulunmaktadır. Büyük amphoraların yer aldığı Sıncak Koyu değişik bir dalış bölgesidir (www.oludenizrotary.com).

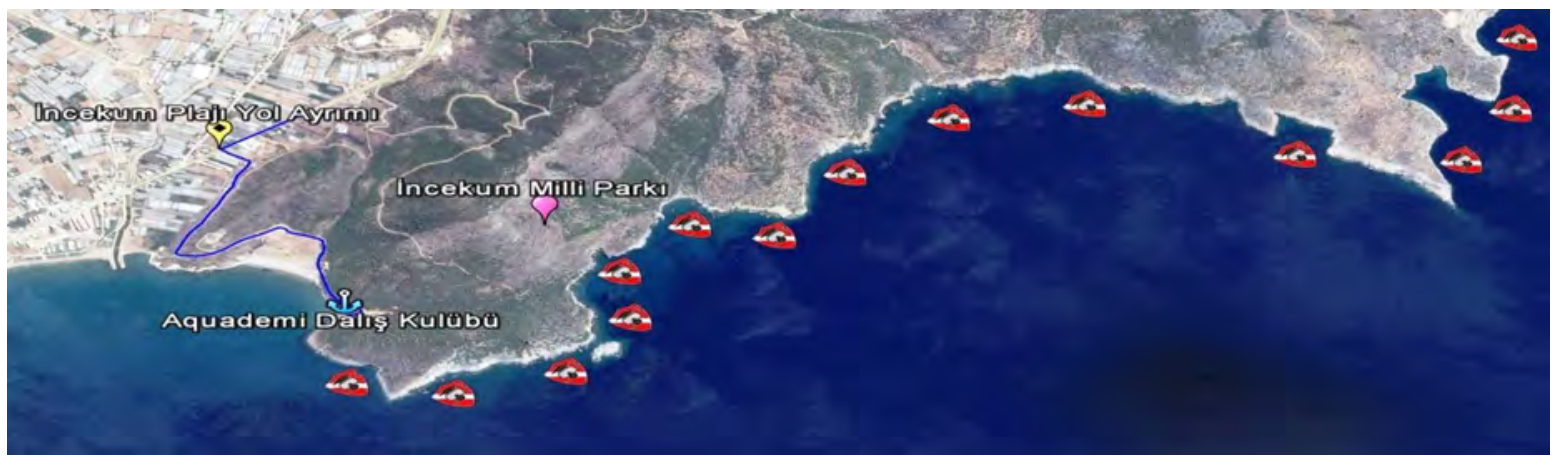

\section{Muğla Bölgesi}

Muğla-Bodrum Dalış Bölgesi: Dünyanın sayılı sualtı müzelerinden birini içinde bulundurmaktadır. Bodrumun doğusunda bulunan Orak adası mağaraları derinliği, değişik renkte süngerleri olan bir dalış merkezidir. Köçek adası istikametin de bulunan 19 metredeki resif' dalınıp görünmesi gereken bir dalış noktasıdır. Bu dalış noktasında her türlü canlıyı görebilme imkanına sahip olursunuz. Çatal adası ve karşı sığlıklar, dalış için enteresan bölgelerdir (www.scubaturkiye.com/tr/).

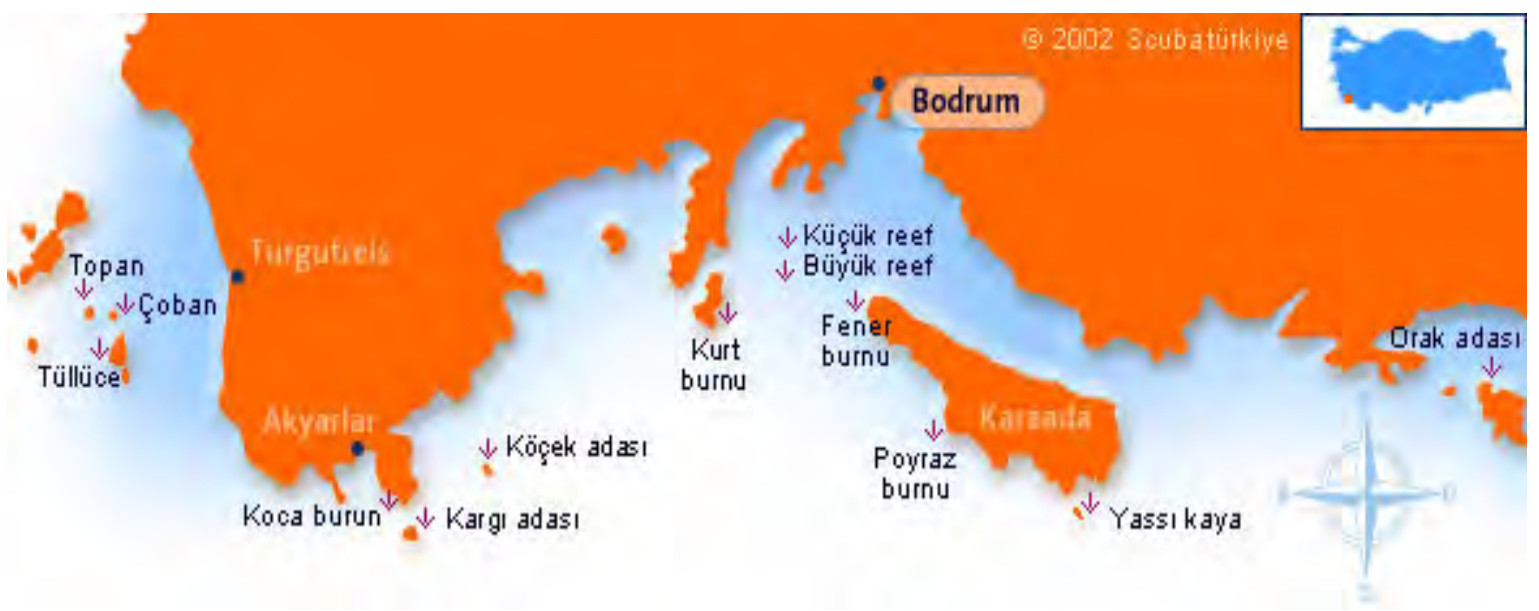

Muğla-Datça Dalış Bölgesi: Datça'da değişik türde adacıklar etrafında, 10-40 metre arasında köpekbalığı, yunus, Akdeniz Foku, kovuk içlerinde 3-4 müren bir arada bulunduğu ender görülebilen dalış noktalarındandır. Esen Adası dalmaya elverişlidir. 
Muğla Marmaris Dalış Bölgesi: 52 dalış noktası, antik kalıntıların bulunduğu Marmaris derinlikleri, her dalgıcın görmek isteyeceği çekiciliktedir. Cennet Adası, Kütük Burnu, Kadırga Feneri ve Kargı Adası önemli dalış noktalarıdır.

\section{Çanakkale Dalış Bölgesi}

Çanakkale Saros Dalış Bölgesi: İstanbul'a ulaşım kolaylı̆̆ı nedeniyle dalgıçların tercih ettiği Saros'ta farklı batıklar bulunmaktadır. Ayrıca Kaptan Franko, Saros körfez bölgesinde Kemiklinin açığında 30 metrede bulunan 'Lundy' dalınabilecek batıklar arasındadır. Siyah mercan bulunmaktadır. Fakat bu bölgede akıntı fazladır (https://yoldaolmak.com).

Çanakkale Bebek ve Minnoş Kayalıklar Alanı: Derinlerde her kaya kovuğunda böcek veya istakoz yavrusu görebilme ihtimalinin olması bölgenin en önemli özelliğidir (Top vd., 2013: 9). Ayrıca deniz salyangozları, müren, iskorpit balıkları görülebilmektedir.

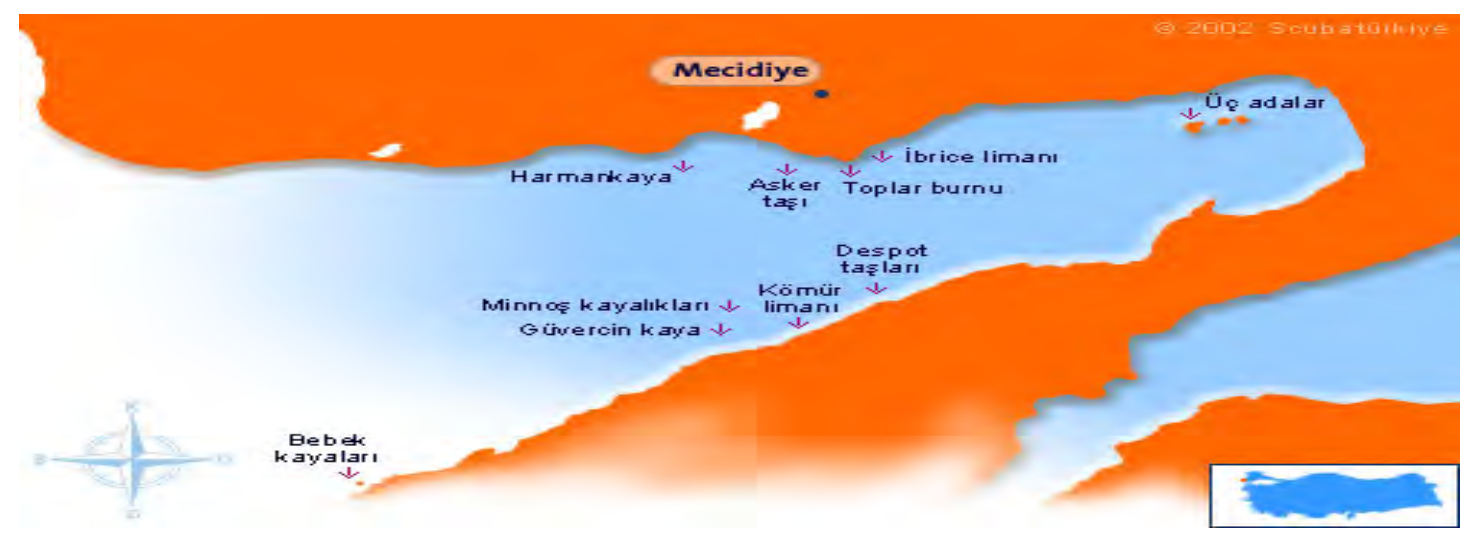

Çanakkale-Gökçeada-Bozcaada Dalış Alanı: Her iki adaya da ulaşım feribotla gerçekleştirilmektedir. Bozcaada kıyıların da hala keşfedilmemiş dalış alanları bulunmaktadır. Eşek adası bölgesin de Orfoz ve Karayer adaları önemli dalış noktalarındandır. Bakla Taşı, Çanak limanı ve Pınar Dere Gökçeada'nın diğer dalış bölgeleridir.

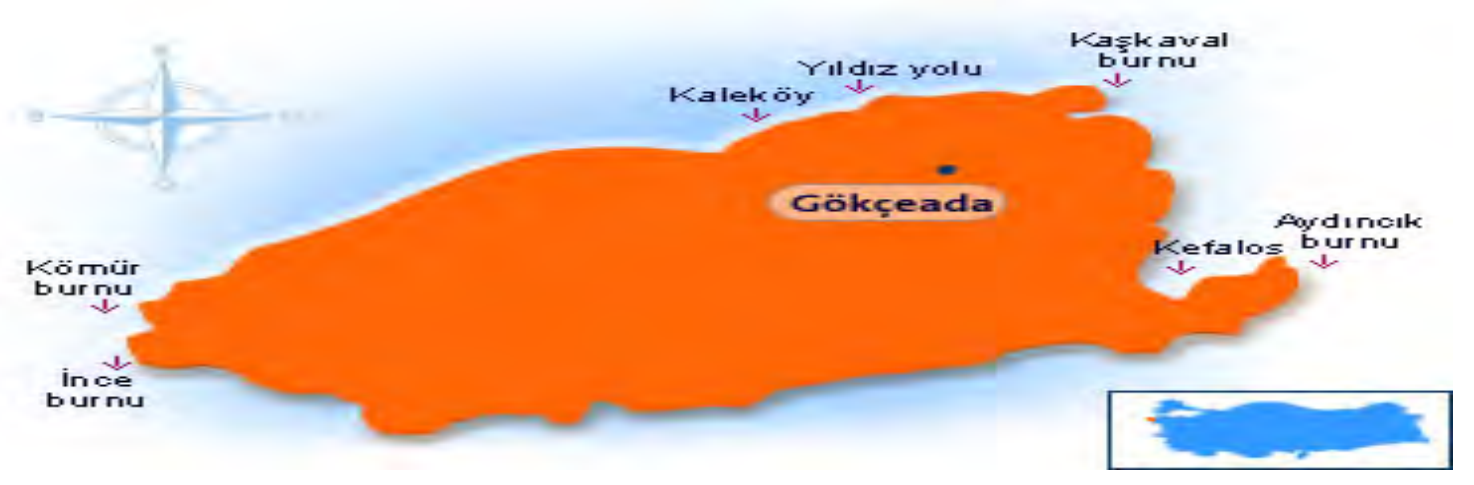

\section{İzmir Dalış Bölgesi}

İzmir-Çeşme Bölgesi: Eşek Adası ve civarındaki küçük adalar oluşturmaktadır. 


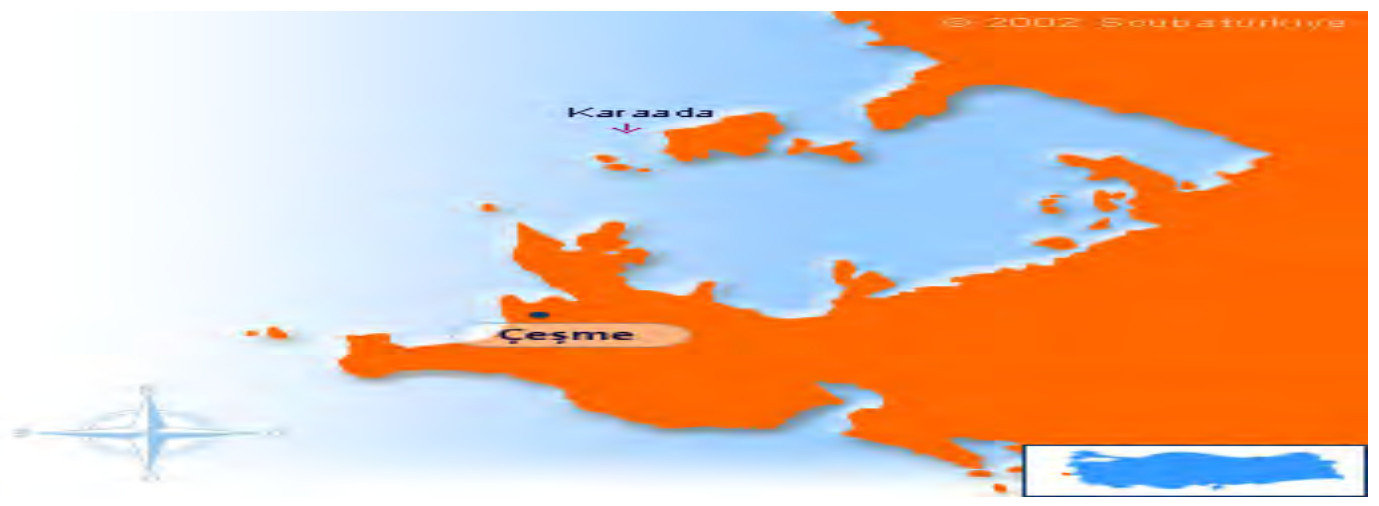

Fener Adası Alanı: Ada iki dalış noktasından oluşmaktadır. Her iki dalış noktasında sı̆̆ olması nedeniyle genelde ikinci dalışlar için tercih edilmektedir.

Yatak Odası Alanı: Mağara içine 3-5 kişi girebilecek kapasitededir.

\section{Aydın Dalış Bölgesi}

Aydın-Kuşadası Dalış Bölgesi: Kuşadası turizm merkezleri açısından önemli bir destinasyon olmasına rağmen su altı turizmi açısından fazla bilinirliği olan bir dalış noktası değildir.

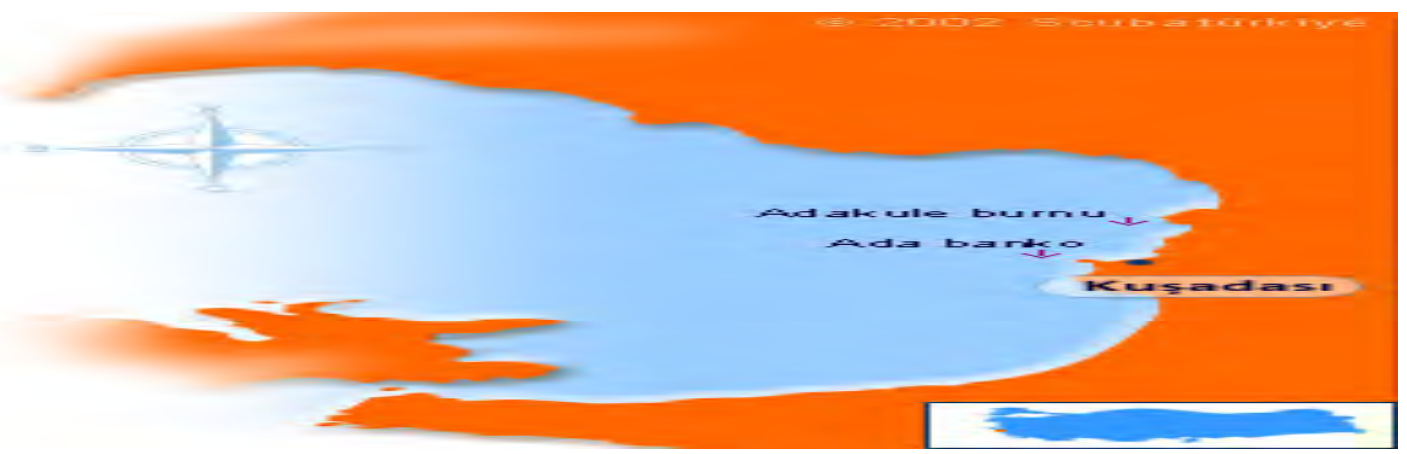

Ada Banko Alanı: Kuşadası ile bütünleşen güvercin adasının 1 mil açığında yer alan bir resiftir.

Pamucak Resifi Alanı: Deneyimli dalgı̧̧lara hitap eden dalış noktalarından biridir.

Adakule Mağarası Alanı: Derinlik 15 metredir. Giriş kısmı 7 metreden başlar 25 m Dar bir alandan ilerleyerek tepesi açık bir mağaraya varılır bu sayede dışarı görülür.

Akvaryum Resifi Alanı: Genel olarak Tecrübeli dalgıçlara uygun bölgedir. Akvaryum resif alanı 20 metreye kadar uzanır.

\section{Balıkesir Dalış Bölgesi}

Balıkesir-Ayvalık Dalış Alanı: Ayvalık, ender olan çekici dalış imkanlarına sahiptir. Güneş Adası, Yuvarlak Ada, Kerbela Taşları dalış bölgeleri mevcuttur. En ünlü dalış noktası ise; Kız Adasının açık denize bakan kısmıdır. $19 \mathrm{~m}$ derinlikte başlayan sualtı faunası su altı meraklıları için gerçekten görülmeye değer vazgeçemeyecekleri ender yerler arasındadır. 


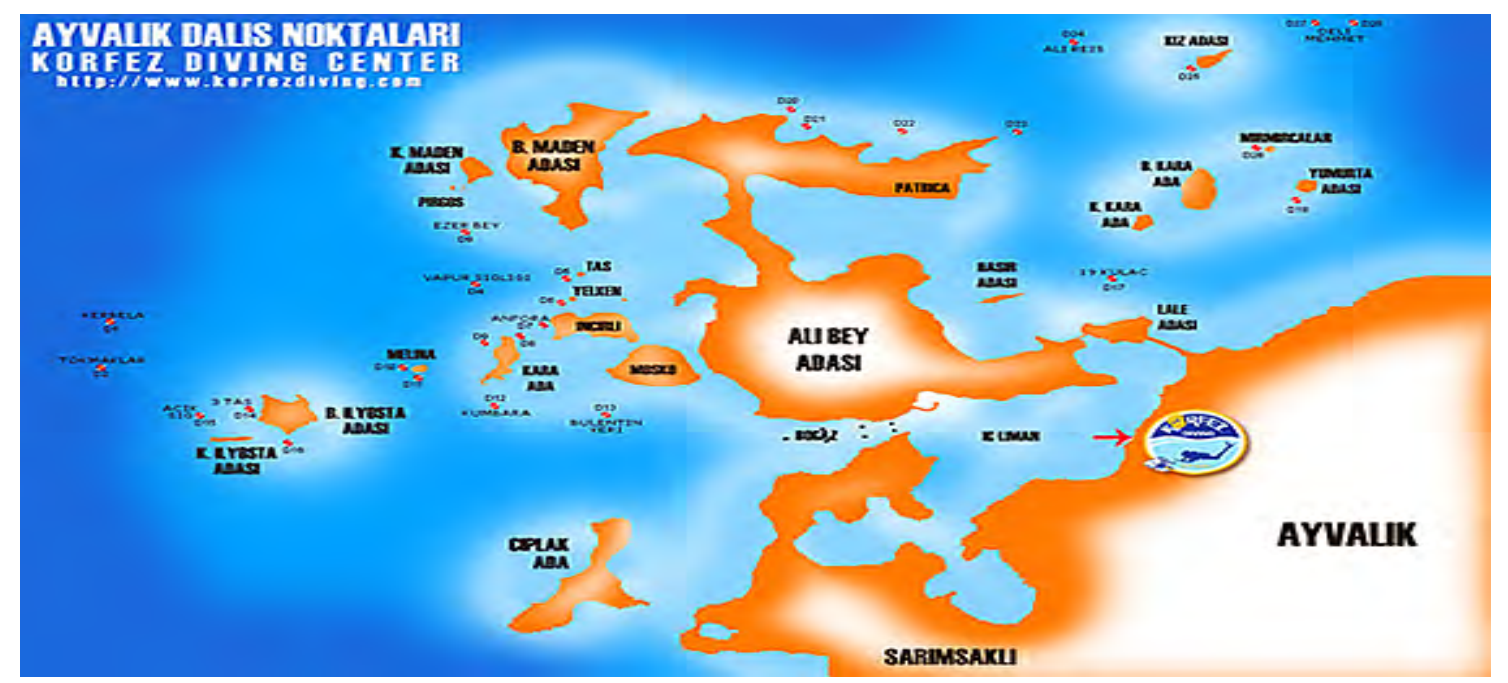

\section{AYVALIK'TA SUALTI TURIZMI}

Ayvalık, doğal, tarihsel ve kültürel değerlere irili ufaklı şirin koylara sahip sadece Ege Bölgesinin değil, Aynı zamanda Türkiye'nin en güzel tatil destinasyonlarından biri olarak görülmektedir. İklim koşulları, nitelikli turistik alt yapısı, ender güzellikteki koyları, berrak ve tertemiz deniz suları ile sualtı turizmi merkezi olabilecek niteliklere sahip bir destinasyon konumdadır. Ancak Ayvalık'ta sualtı turizmi Malta ya da Kızıldeniz'deki kadar gelişmediği gibi, bugüne kadar bu turistik ürün grubuyla ilgili yeterli tanıtım da yapılamamıştır. Ayvalık zengin sualtı değerlerine sahip olmasına rağmen, bu değerleri yeterli düzeyde gösterebilecek dalış merkezlerinin olmaması ve sezonun kısa olması nedeni ile atıl kaldığını söyleyebiliriz. Yaptığımız araştırmalarda bölgede; bu konuda dört aktif dalış merkezi vardır ancak teknik donanım ve dalış teknesinin özel tasarımları ile iki merkez öne çıkmaktadır. Kuzey Ege'de önemli bir dalış noktası olan Ayvalık'ta sualtı dalış yapmak isteyenlere hizmet veren 4 ayrı dalış okulunda yılın yaklaşık on ayında dalış yapılabilmektedir. 24 adası 60 dalış noktası bulunan Ayvalık'a başta Alman turistler olmak üzere Sırbistan, Hollandalı, Fransız, İngiliz, Bulgar turistler dalış eğitimi almak ve kentin sualtı güzelliklerini görmek için gelmektedir (Gökdeniz ve Erdem, 2015:24).

Ayvalık destinasyonun da mercan reefleriyle beraber yaklaşık 60 adet dalış noktası bulunmaktadır (Gökdeniz ve Dinç, 2013:247). Bu dalış noktalarında; Turistleri mutlu edecek her türlü canlı ve tüplü kurt tarlaları, sarı ve kırmızı mercanlar, süngerler ve Bizans anfora kalıntıları bulunmaktadır. Destinasyon Bölgesi, 24 adadan oluşmaktadır. Rüzgâr nereden eserse essin dalgıçların rahatça dalış yapacakları sakin dalış noktaları mutlaka mevcuttur. Bu özelliğiyle Ayvalık, diğer dalış bölgelerinden bir adım öne geçmektedir (http://dalisrehberi.com). Havanın kötü olduğu zamanlarda bile mutlaka dalışa uygun bir bölge bulunur. Ege denizinin kuzey bölümün de yer alan 24 adacıktan oluşan Ayvalık destinasyonu, dalgıçlar tarafından en çok tercih edilen dalış bölgeleri arasında ilk sırayı almaktadır (Gökdeniz, 2014:32). Bölge, mercan reefleri açısından çok renkli zengin dip yapısı ve berrak denizi ile sualtı fotoğrafçıları için mükemmel görüntü imkânları sunmaktadır. Özellikle bölge denizinin akıntı durumu, plankton zenginliği, su sıcaklığının her mevsim dalışa olanak sağlaması ve başka bir yerde bulunmayan kırmızı mercanlara (gorgonia-corallium rubrum) sahip olması bölgenin dalış turizminde önemli avantajıdır (Gökdeniz vd., 2010:167). Bu kırmızı mercanın yani bu türün bir benzeri İtalya Portofino kenti açıklarında bulunmaktadır. Ayvalık; akıntı debisi ve derinlik açısından gece ve reef dalışları için mükemmel bir dalış bölgesi özelliği taşımaktadır ve 
her seviyedeki dalgıçlar için değişen derinlikte dalış noktalarına sahiptir. Dalış noktalarından bazıları; Deli Mehmet reef I, Deli Mehmet reef II, Kerbela, Kule reef, Ali Reis sığlığı, Barbonaksa sığlığı, Vapur sığlığı I ve II, Tokmaklar reef, 19 kulaç gibi alanlardır. Ayvalık bölgesinde 12 ay boyunca rahat dalış imkanı sağlayacak 4 dalış okulu vardır.

Ayvalık Bölgesi'nde sualtı flora ve fauna çeşitliliği diğer merkezlere oranla yüksektir. Ancak; trol, mevsim dışı kaçak avcılık, bölgedeki yerleşimden kaynaklanan arıtmasız pis su atıkları gibi etkenlerden dolayı sürekli tahrip edilmekte ve yeterince korunamamaktadır. Bu noktada, Ayvalık'ta sualtı turizmi açısından tespit ettiğimiz sorunları şöyle sıralayabiliriz;

* Ayvalık turizmi içerisinde sualtı değerlerine talep, yeterli değildir. Özellikle yabancı turist talebi çok azdır. Bu konuda yeterli tanıtım ve organizasyon çalışmaları sektör temsilcilerinin özel girişimleri, Ayvalık Turizm Geliştirme Birliği (AYTUGEB) ve Ayvalık Belediyesi sayesinde olmakta, ancak bu çabalar çok yeterli ve etkin değildir.

* Sualtı değerlerini turizme kazandırma çabasıyla Ayvalık'taki yerel yönetim, merkezi yönetim, üniversite ve sektör temsilcilerinin işbirliği ile yapılan çalışmalar yetersizdir.

* Sualtı değerlerinin gösterilmesini sağlayacak dalış kursları bireysel maliyetler açısından yüksektir.

* Dalış kurslarına ilişkin eğitim verebilecek dalış okullarının sayısı az yeterli değildir.

* Malta ve Florida gibi merkezlerde, sualtı flora ve faunasını zenginleştirmek ve korumak amacıyla oluşturulan yapay resifler ve batıklar dalış meraklılarının büyük ilgisini çekmektedirler (Bal, 2002:55). Ayvalık'ta bu sporu geliştiren, renklendiren ve çekici hale getiren doğal sualtı formasyonları yetersizdir. Yapay formasyonlar ise; hiç yoktur.

* Bölgenin iklimi, hava ve su sıcaklıkları yılın 4 mevsiminde bu sporun yapılmasına imkan vermektedir. Örneğin; yaz ve kış sualtı turizmi yapılan Malta ile Ayvalık'ın aynı iklim kuşağında yer alması, bizim bölgemizde de turizmin yıl boyunca kesintisiz olarak yapılabilirliğini ortaya koymaktadır. Ancak, popüler kitle turizmi ile bu olanağın sağlanması bugüne kadar bu destinasyon için mümkün olmamıştır (www.alternatiftur.com).

* Dünyadaki turizm merkezlerinin önemli bir kısmı sualtının görsel çekiciliğine sahip olmasına rağmen, deniz kirliliği nedeniyle tehdit altındadır. Bu olumsuz etkenler maalesef Ayvalık destinasyonunda da görülmektedir.

* Ayvalık'ta faaliyet gösteren dalış okullarının hizmet verdiği toplam dalgıç sayısı son derece düşüktür. Ayrıca, bu okullar kapasitelerini yalnızca turizm sezonunda (Nisan-Ekim ayları arası) verimli olarak kullanabilmektedir. Dünyanın popüler dalış (mısır gibi) merkezlerinde bilinçli biçimde oluşturulan hizmet kapasiteleri, Ayvalık ile kıyaslanamayacak oranda büyüktür.

* Ayvalık'ın bugüne kadar turizm geliştirme / master planı hazırlanmadığı için, genele ve sualtı turizmine yönelik bölgesel politikalara planlı bir destek oluşturulamamaktadır. Dünyanın popüler dalış merkezlerinde sualtı turizmi, Mısır, Malta ve Küba örneklerinde olduğu gibi, bölgesel ve ülkesel ölçeklerde devlet ve hükümet politikası olarak planlanmakta, desteklenmekte ve hatta yürütülmektedir. 


\section{SONUÇ ve ÖNERILER}

Turizm sektörü, birçok sektöre doğrudan ve dolaylı olarak destek sağlamaktadır. Örneğin; günümüzde turizm sektörü özellikle gelişmekte olan ekonomiler için önemli bir gelir kaynağ olmakla birlikte, istihdama da önemli katkı sağlayan bir sektör haline gelmiştir. Bu noktada; etkili bir turizm planlaması ile sektörün GSMH içindeki payı daha da yükselecektir. Son yıllarda eko-turizm çerçevesinde talep edilen bir alternatif turizm çeşidi haline gelen sualtı dalış turizmi üzerinde durulması ve değerlendirilmesi gereken önemli bir turistik ürün grubudur. Türkiye; özellikle sualtı sporlarıyla ilgilenenler için dünyada eşine az rastlanan dalış bölgelerine sahiptir. Bu dalış bölgeleri, sualtı zenginliklerinin yanı sıra, gizliliğini ve çekiciliğini hâlen sürdürmekte ve keşfedilmeyi beklemektedir. Ayrıca, bu spor dalı artık yerli ve yabancı turistlerin de önemli bir aktivite alanı olmaya başlamıştır.

Ayvalık'ın alt ve üst yapısı, konaklama hizmetleri ve turizm çeşitliliği, dünyadaki diğer dalış merkezleri ile benzer standartlardadır. Tarihsel, doğal ve kültürel zenginlikler açısından ise Ayvalık, bir açık hava müzesini andıran kıskanılacak güzellikteki değerlere sahiptir. Bu noktada yaptığımız araştırma sonucuna göre tüm bulgular göz önüne alınarak hem Türkiye'de hem de Kuzey Ege'de (Ayvalık) sualtı dalış turizmin gelişmesi ve sürdürülebilirliğin sağlanması için şunları söyleyebiliriz;

- Sualtı dalış turizminin; bölgelere yarattığı ekonomik katkı ve talep tercihinde gözlenen büyük gelişme ile yakın gelecekte en çok tercih edilecek turistik ürün gruplarından biri olacağı anlaşılmaktadır. Bu noktada, başta destinasyon yöneticileri başta olmak üzere bu turizm türünün tüm paydaşlarının sürdürülebilirlik, pazarlama, rekabet avantajı ve ekolojik çevre konusunda dikkatli olması gerekmektedir.

- Ayvalık'ta yaptığımız araştırma çerçevesinde, dalış noktalarında şamandıra uygulaması bazen uygulanmakta bazen ise uygulanmamaktadır. Şamandıra uygulaması tüm dalış noktalarında sualtı flora ve faunasının devamlılığı açısından son derece hayati bir konudur.

- Sualtı dalışı yapacak tüm bireylerin dalış öncesi mutlaka eğitime tabi tutulması gerekmektedir. Çünkü bu eğitim hem kendi canları hem de su altı yaşamının korunması ve devamı açısından önemlidir.

- Araştırmada sualtı dalışı ile ilgili karşımıza çıkan bir diğer sorun ise; atıklardır. Bu soruna yönelik olarak hem dalış teknelerinin hem de STK'ların sualtı ve suüstü atıklar konusunda farkındalık oluşturması gerekmektedir. Bu soruna yönelik periyodik eğitimler verilebilir ve dikkat çekici broşür ve afişler hazırlanabilir. Bu noktada diğer önerilerimiz ise şöyledir;

- Sualtı arkeolojik varlıkların korunması ve talan edilmemesi için bu değerlerin bulunduğu kıyı kesimlerinin dalışa yasak alanlar olarak ilan edilip, koruma altına alınmalıdır.

- Dalış yasağı bulunmayan ticari alanlarda deniz florası ve faunasına trolle yapılan avcilık büyük zarar vermektedir. Bu avcılık türü yasaklanarak, sualtı dalış turizminde çekicilik yaratan unsurların korunması sağlanabilir.

- Dalış noktalarında aletle dalış yapanların zıpkınla avcılık yapmasına izin verilmemeli veya önlenmelidir. Bu alanlarda Sahil Güvenlik ve Jandarmanın denetimleri artırılmalıdır. 
- Dalma (dalgıç) ehliyeti alma sürecinin zorlaştırılması ve bröve alma süresinin uzatılması bir başka caydırıcı önlemdir. Böylelikle, gerçekten bu turizm ve spor dalına ilgi duyanların önü açılmış olacaktır.

- Ayvalık ve Adalar Bölgesi'nin dalış turizmi potansiyeli yüksektir. Ancak bu bölgeleri koruyarak kullanma ve geliştirerek koruma ilkesi hiçbir zaman göz ardı edilmemelidir.

Su altı dalışlarında yani basınç farkından dolayı oluşan rahatsızlıklar için basınç merkezi olan tam donanımlı hastane kurulmalıdır. Su altı dalmanın en fazla yapıldığı körfez ilçesi Ayvalıkta vakit geçirilmeden bu hastanenin tahsis edilmesi gerekmektedir.

- Mısır'ın istikrarsız ve güvenilir bir ülke olmasından yola çıkılarak, o bölgeye olan dalış turizm potansiyeli ülkemize çekilebilir. Bu gruplara yönelik etkili bir tanıtım ve reklam kampanyası düzenlenerek talep ülkemize çekilebilir.

- Son olarak Ayvalık'taki gezi teknelerinin veya dalış okulu teknelerinin tabanları sualtı zenginliğini, sualtı flora ve faunasını görecek şekilde tasarlanması bu spora olan talebi artıracaktır.

\section{KAYNAKÇA}

Akşit, S. (2007), Doğal Ortam Duyarlılığ1 Açısından Sürdürülebilir Turizm, Erciyes Üniversitesi, Sosyal Bilimler Enstitüsü Dergisi, 2(23), 441-460.

Bal, C. (2002), Biyoçeşitlilik ve Turizm, II. Turizm Şurası Bildirileri, 12-14 Nisan 2002, Ankara, 54-57.

Batı Akdeniz Kalkınma Ajansı (2012). Ekoturizm Sektör Raporu, [Çevrim-içi: http://www. baka.org.tr /uploads/1349952547Ekoturizm-Sektor-Raporu, (12.12.2017)

Bideci, Ç., (2014), Turizmde Ürün Farklılaştırılmasında Sualtı Kültürel Miras Alanlarının Turizm Ürünü Olarak Kullanımı, Replika Gemi Batığı Projesi: Side Örneği, Akdeniz Üniversitesi Sosyal Bilimler Enstitüsü, Turizm İşletmeciliği ve Otelcilik Ana Bilim Dalı Yayınlanmamış Yüksek Lisans Tezi, Antalya.

Demirtaş, D. (2012). Türkiye'de Sürdürülebilir Turizm Kapsamında Su Altı Dalış Turizmi ve Rafting Turizmi, 13. Ulusal Turizm Kongresi, 6-9 Aralık 2012 Antalya.

Erkurt, O. ve Paker, S. (2014). Sualtı Arkeoparkları ve Deniz Turizmi, 2. Ulusal Deniz Turizmi Sempozyumu, Dokuz Eylül Üniversitesi, 49-61.

Gorrad, B. and Gissling, S., (2008). New Frontiers in Marine Tourism, Diving Experiences, Sustainability, Management, Oxford.

Gökdeniz, A., and Dinç Y., (2013). A Proposal For A Sustainable Model Based Upon Underwater Tourism Research In Ayvalık, Air and Water Components of the Environment Confrence, httpaerapa.conference.ubbcluj.ro2013pdf35\%20gokdeniz \%20245_254.pdf, ClujNapoca, Romania, 245-254.

Gökdeniz, A., ve Erdem B., (2015). Turizm Politikasında Ekonomik Başarı Koşulları ve Ayvalık Örneği, Marmara Sosyal Araştırmalar Dergisi, 7, 1-32

Gökdeniz, A., (2014). Sürdürülebilir Turizm ve Ayvalık Su Altı Dünyası, Ayvalık Belediyesi Yayınları, Ayda Bir Ayvalık Dergisi, 3, 32-33. 
Gökdeniz, A., Dinç, Y., Akşit, A. N. ve Münger, L. (2010). Ayvalık'ta Su Altı Turizm Araştırması, Detay Yayıncilık, Ankara.

http://www.scubaturkiye.com/tr/Locations/default.asp?LocId=20(ErişimTarihi: 12.02. 2018).

https://yoldaolmak.com/turizm-ve-tatil-sehri-sarm-el-seyh-misir.html,(ErişimTarihi:10.02. 2018).

http://dalisrehberi.com/makaleler/misir-da-dalis (ErişimTarihi:20.02.2018)

https://www.statista.com/statistics/814613/caribbean-tourism-revenue/ (Erişim Tarihi 15.03.2021)

https://www.nytimes.com/2019/02/05/travel/galapagos-overtourism.html (Erişim Tarihi 15.03.2021)

https://wwwdivescover.com (Erişim Tarihi 15.03.2021)

https://www.gbrmpa.gov.au/our-work/Managing-multiple-uses/tourism-on-the-great-barrierreef/visitor-contributions2/numbers (Erişim Tarihi 15.03.2021)

https://www.wttc.org./researc/economicimpact/moduleld/704/itemld/105/controller/downloadr equest/action/quickdownload (Erişim Tarihi 15.03.2021)

Kültür ve Turizm Bakanlığı (2015). Su Altı Dalış Turizmi, [Çevrim- içi:http: //yigm.kulturturizm.gov.tr/TR,11517/su-alti-dalis.html], Erişim Tarihi:(12.12.2017)

Özbek M., (2014). Turizm Amaçlı Su Altı ve Su Üstü Sportif Faaliyetler: Bugünü Geleceği, Dokuz Eylül Üniversitesi Denizcilik Fakültesi Dergisi, 6 (2), 27-48.

Polonsky, M. J. and Rosenberger III, P. J., (2001). Reevaluating Green Marketing: A Strategic Aproach, Business Horizons, September - October 2001, 21-30.

Şenok, F. (2001). Türkiye Dalış Rehberi, Net Turistik Yayınları A.Ş. Yay, İstanbul.

Top, B., Yolak, U. and Thomas, L. (2013). Foça Özel Çevre Koruma Bölgesi Sportif Dalış Turizmi FizibiliteÇalışması,[Çevrimiçi:http://dcm.dka.gov.tr/App_Upload/17_Foca\%20Ozel\%0Cevre\%2 0Koruma\%20Bolgesi\%20Sportif\%20Dalis\%20Turizmi\%20Fizibilite\%20Calismasi.pdf]， (Erişim Tarihi: 10.12.2017).

Yarmacı N., Keleş Melike Ç. ve Ergil B., (2017). Su Altı Dalış Turizminin Mevcut Durumu, Sorunları ve Geliştirilmesine Yönelik Öneriler: Kaş Örneği, Güncel Turizm Araştırmaları Dergisi, $1(1), 66-87$.

Yaşar, O., (2011), Saroz Körfezi Kıyılarında Su Altı Dalış Turizmi (Underwater Diving Tourism on the Coasts of The Gulf of Saros), Zeitschrift für die Welt der Tüken, Journal of Word of Turks, $3(1), 33-55$.

www.oludenizrotary.com/index.php/lang.../77-sualti-turizmi (Erişim Tarihi 04.12.2017)

www.alternatiftur.com (Erişim Tarihi 24.12.2017)

www.tatilium.com (Erişim Tarihi 10.03.2018) 